Tropical Journal of Pharmaceutical Research November 2018; 17 (11): 2199-2206

ISSN: 1596-5996 (print); 1596-9827 (electronic)

(1) Pharmacotherapy Group, Faculty of Pharmacy, University of Benin, Benin City, 300001 Nigeria.

\title{
Optimization of L-asparaginase activity of Actinobacteria isolated from Guaviare river sediments in Colombia
}

\author{
Maria Morales-Gonzalez, Boghos Stepanian Martinez, Laura Ramirez- \\ Rodriguez, JEC Gómez, LE Diaz* \\ La Sabana University, Engineering Faculty, Campus del Puente del Común, Km 7 Autopista Norte de Bogotá. Chia, Colombia \\ *For correspondence: Email: luisdb@unisabana.edu.co; Tel: +57 18615555 ext 25208
}

Revised accepted: 19 October 2018

\begin{abstract}
Purpose: To optimize the L-asparaginase activity of Actinobacteria isolated from Guaviare river sediments in Colombia.

Methods: Actinobacterial strains were evaluated for their L-asparaginase activity using phenol red plates and Nessler's assays. Strains with L-asparaginase activity were identified based on $16 S$ ribosomal rRNA sequencing, and a central composite design was used to study nutritional and growth factors that could improve $L$-asparaginase activity. $L$-asparaginase protein was detected using western blotting and the cytotoxicity of L-asparaginase preparations was evaluated against MDA-MB231 and L929 cell lines.

Results: Kitasatospora atroaurantiaca, Streptomyces griseoluteus, and Streptomyces panaciradicis were cultured in medium with lactose as a carbon source and a combination of asparagine and malt extract as nitrogen sources. These strains showed L-asparaginase activities of 29.4, 114.06, and 34.08 $\mathrm{U} / \mathrm{mg}$, respectively, and half-maximal inhibitory concentration $\left(I_{50}\right)$ values of $25.61 \pm 2.15,8.18 \pm 1.61$, and $165.29 \pm 1.06 \mathrm{ppm}$, respectively, against MDA-MB 231 cells. Western blotting analysis revealed the presence of an L-asparaginase monomer with a molecular weight of $37 \mathrm{kDa}$.

Conclusion: Kitasatospora atroaurantiaca, Streptomyces griseoluteus, and Streptomyces Panaciradicis produce L-asparaginases with low L-glutaminase activity and promising cytotoxic activity and thus may be useful for the management of acute lymphoblastic leukemia.
\end{abstract}

Keywords: L-asparaginase, Streptomyces, Kitasatospora, Optimization, Cytotoxicity

\begin{abstract}
This is an Open Access article that uses a funding model which does not charge readers or their institutions for access and distributed under the terms of the Creative Commons Attribution License (http://creativecommons.org/licenses/by/4.0) and the Budapest Open Access Initiative (http://www.budapestopenaccessinitiative.org/read), which permit unrestricted use, distribution, and reproduction in any medium, provided the original work is properly credited.
\end{abstract}

Tropical Journal of Pharmaceutical Research is indexed by Science Citation Index (SciSearch), Scopus, International Pharmaceutical Abstract, Chemical Abstracts, Embase, Index Copernicus, EBSCO, African Index Medicus, JournalSeek, Journal Citation Reports/Science Edition, Directory of Open Access Journals (DOAJ), African Journal Online, Bioline International, Open-J-Gate and Pharmacy Abstracts

\section{INTRODUCTION}

L-asparaginase (L-asparagine amidohydrolase, EC 3.5.1.1) is a potential anti-cancer enzyme. This enzyme decreases the L-asparagine concentration by catalyzing the deamination of the amino acid into L-aspartic acid and ammonium, leading to cell death [1]. Patients with acute lymphoblastic leukemia (ALL) are treated with Escherichia coli L-asparaginase; however, they can suffer an adverse reaction because of the L-glutaminase activity together with the short half-life of the enzyme [3-4]. Survival in pediatric patients with ALL has

(C) 2018 The authors. This work is licensed under the Creative Commons Attribution 4.0 International License 
improved significantly: Nearly $90 \%$ of children are cured using L-asparaginase [5].

Therefore, there is a high demand for oncolytic enzymes because cancer cells are more sensitive to them [2]. L-asparaginases produced by microorganisms and plants have been studied, and several attempts have been made to increase their activity [9-12] using different experimental designs, such as the Box-Behnken [13] and Plackett-Burman [12] methods. Likewise, attempts have been made to produce enzyme recombinantly, employing techniques such as directed evolution and epitope engineering, to introduce the gene into $E$. coli [8]; however, the recovery of the enzyme was low, it showed poor biochemical properties [6], and was impure [7]

Thus, the present study focused on searching for novel sources of $\mathrm{L}$-asparaginase with low Lglutaminase activity, and the effects of Lasparaginase from Actinobacteria isolated from the Guaviare river (Colombia).

\section{EXPERIMENTAL}

\section{Biological materials}

The strains analyzed belonged to the Actinobacteria biobank of La Sabana University and were isolated from sediments of the Guaviare river [18].

\section{Selection of Actinobacteria with L- Asparaginase or L-Glutaminase activity}

The morphologies of the strains were evaluated on ISP-3 medium (also known as oatmeal agar) using Gram staining and scanning electron microscopy (SEM) (Phenom pro, Thermo Fisher Scientific, Netherlands) [14]. Strains selection was performed using a phenol red plate assay $[15,16]$. Strains were cultured in ISP-5-agar (glycerol-L-asparagine) with $0.009 \%(\mathrm{v} / \mathrm{v})$ phenol red and incubated at $37^{\circ} \mathrm{C}$ for 7 days [15].

\section{Determination of the enzymatic activities}

The enzymatic activities were quantified using nesslerization [16]. The strains were grown in ISP-5 medium at $30^{\circ} \mathrm{C}$, with shaking at $150 \mathrm{rpm}$ (Innova 42R, New Brunswick ${ }^{\mathrm{TM}}$, USA) for seven days. After centrifugation at $5000 \mathrm{~g}$ (Mikro 22R, Hettich, Germany) for 30 min, the biomass was filtered through a $0.22-\mu \mathrm{m}$ pore size hydrophilic polyvinylidene fluoride (PVDF) membrane, washed and dried at $80^{\circ} \mathrm{C}$ for $24 \mathrm{~h}$. The biomass content was measured and the supernatant (5 $\mathrm{mL}$ ) was subjected to nesslerization [16]. The enzymatic activity is expressed in enzyme units $(U)$, which were defined as the amount of enzyme used to release $1 \mu \mathrm{mol}$ of ammonium per unit time $(U=\mu \mathrm{mol} / \mathrm{min})$ [14]. Protein quantification was performed using a bicinchoninic acid (BCA) assay with bovine serum albumin (BSA) at $2 \mathrm{mg} / \mathrm{mL}$ as a standard [17].

\section{Molecular identification of Actinobacteria strains}

The 16S rRNA gene was amplified using polymerase chain reaction (PCR) in a thermocycler (BIO-RAD iCycler, USA) with extracted DNA as the template [18]. The PCR reaction was confirmed by electrophoresis in $1 \times$ Tris-Borate-EDTA (TBE) buffer and compared with a ladder of molecular markers

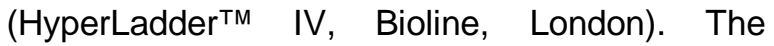
amplicons were sequenced by BIOS-SIB (Colombia) and compared with entries in the GenBank databases and evaluated according to their percent identity.

\section{Western blotting}

Protein extracts $(30 \mu \mathrm{g})$ were separated by sodium dodecyl sulfate polyacrylamide gel electrophoresis (SDS-PAGE) and transferred to nitrocellulose membranes using a Semi-Dry Blotter (EU-4000, C.B.S. Scientific Company Inc, USA) for 30 minutes at $100 \mathrm{~V}$. The membranes were blocked with $5 \%$ non-fat dry milk-TBST (Tris-buffered saline-Tween 20) buffer for $1 \mathrm{~h}$ and incubated overnight at $4{ }^{\circ} \mathrm{C}$ with a 1:1000 dilution of anti-L-asparaginase antibodies conjugated with horseradish peroxidase (HRP) (GTX 40848, GeneTex) in $1 \%$ non-fat dry milk-TBST buffer. Bands were detected using myECL Imager (Thermo Scientific, USA). A commercial Lasparaginase (Medac $\mathrm{GmbH}$, Hamburg, Germany) was used as the positive control.

\section{Evaluation of the effect of carbon and nitrogen sources on the L-asparaginase activity}

The best three carbon sources were determined among soluble starch, lactose, glycerol, glucose and sucrose $[2,10,15,19]$ at $1 \%(\mathrm{w} / \mathrm{v})$ each, using the phenol red plate assay $[15,20]$. The best carbon source was then confirmed using nesslerization. The same tests were performed to determine the best nitrogen source among meat extract, yeast extract, potassium nitrate, peptone, malt extract, L-asparagine, and Lglutamine $[6,20]$ at $1 \%(\mathrm{w} / \mathrm{v})$, and two combinations of $\mathrm{L}$-asparagine with malt extract or potassium nitrate (both at $0.05 \%$ ). 
Optimization of nutritional and growth factors

The influence of different nutritional and fermentation conditions on the L-asparaginase Table 2). The experimental results of CCD were fitted by the response surface regression procedure using a second order polynomial equation:

$Y=\beta_{0}+\sum_{i=1}^{n} \beta_{i} x_{i}+\sum_{i=1}^{\Gamma-1} \sum_{z=1+1}^{n} \beta_{i j} x_{i} x_{i}+\sum_{i=1}^{n} \beta_{i i} x_{i j}^{2} \ldots \ldots$ (1)

where $Y$ is the predicted response, $\beta_{0}$ is the regression coefficient, $\beta_{i}$ is the linear coefficient, $\beta_{i i}$ is the quadratic coefficient, $\beta_{i j}$ is the interaction coefficient, and $X_{i}$ is the coded level of the independent variables [12].

\section{Evaluation of cytotoxic activity}

Cell cultures of MDA-MB-231 (ATCC ${ }^{\circledR}$ HTB-26 TM_ Breast cancer) and L929 (ATCC ${ }^{\circledR}$ CCL-1 ${ }^{\text {TM }}$ mouse fibroblasts) were seeded into 96-well plates in $100 \mu \mathrm{L}$ of Dulbecco's modified Eagle's medium (DMEM) and incubated for $24 \mathrm{~h}$ at $37^{\circ} \mathrm{C}$ and $5 \% \mathrm{CO}_{2}$. L-asparaginase preparations were added (10-200 ppm; 0.26-6.14 mU/mL) for 48 h. Cytotoxic activity was evaluated using the 3(4,5-dimethylthiazol-2-yl)-2,5-diphenyltetrazolium bromide (MTT) test [21]. L929 cells were used as the untransformed control cell line. Doxorubicin (1-20 ppm) was used as the cytotoxic positive control.

\section{Statistical analysis}

Analysis of variance (ANOVA) was applied to the established regression and was carried out for the experimental designs and the models, with statistical significance defined as $p<0.05$, in Design Experts ${ }^{\circledR}$ v7 software. The surface plots were constructed using STATISTICA software.

\section{RESULTS}

\section{Actinobacteria with L-asparaginase and/or L- glutaminase activity}

Gram-positive bacteria with the typical morphology of the Actinobacteria (Figure 1 A-D) were identified using Gram staining and SEM. Actinobacteria showed white aerial and gray vegetative mycelia (Figure 1E), with well-developed and non-fragmented hyphae, with ramifications accompanied by fragments stick or coconut form, the presence of spores in spiral chain on the aerial mycelium (Figure 1F), and the presence of branched thin filaments and spiral structures ( activity was determined using a small central composite design (CCD) with five levels of each factor (

Figure 1G); Among 375 strains tested, 20 presented L-asparaginase and/or L-glutaminase activity, as determined by the phenol red assay $[1,10]($

Figure $1 \mathrm{H})$.

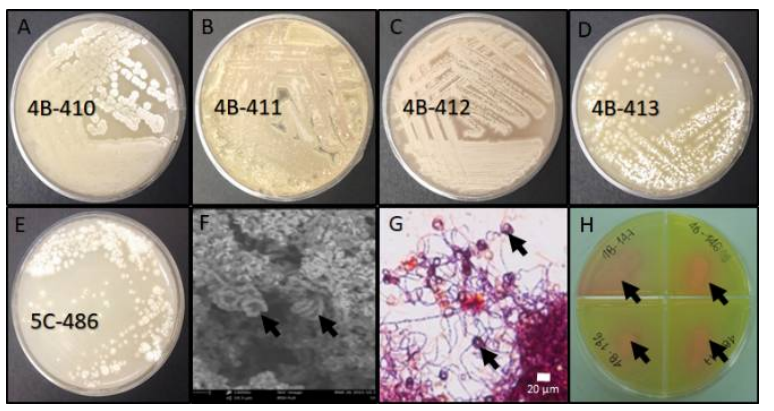

Figure 1: A-E: L-asparaginase producing strains grown on ISP3-agar. F-G: Microscopic features of strain 4B-413 (14000x) observed using scanning electron microscopy (SEM) and Gram staining. Arrows show the presence of spores in spiral chains on aerial mycelium. $\mathrm{H}$ : Actinobacteria strains identified as positive for the liberation of ammonia by Lasparaginase and/or L-glutaminase activity

Five strains showed higher L-asparaginase than L-glutaminase activity (

Figure 2). Strain 4B-413 showed the highest Lasparaginase activity with an L-asparaginase/Lglutaminase ratio of almost 200 .

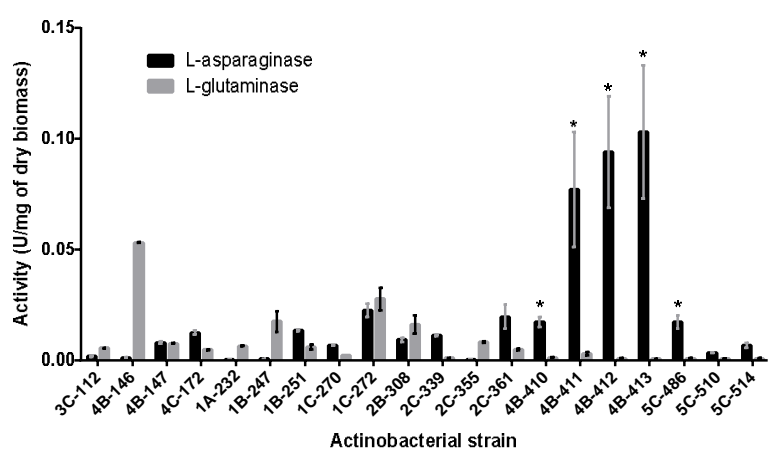

Figure 2: L-asparaginase/L-glutaminase activities of 20 actinobacterial strains. The results are shown as mean $\pm S D(n=3)$. ${ }^{*}$ Strains selected for further research

\section{Molecular identification of Actinobacteria}

The five strains (L-asparaginase producers) were identified as Kitasatospora atroaurantiaca (4B410), Streptomyces seoulensis (4B-411), Streptomyces griseoluteus (4B-412), Streptomyces panaciradicis (4B-413) and Streptomyces $\mathrm{sp}$. (5C-486), using Chromas ${ }^{\circledR}$ [13] and Bioedit ${ }^{\circledR}$ to 
obtain the consensus sequences, which were aligned using BLAST $^{\circledR}$ [22]. Each strain presented identities greater than $99 \%$ with the sequences deposited in GenBank.

\section{Western blotting}

Bands with a molecular weight of $37 \mathrm{kDa}$ were detected for the five strains (as an example Figure 3 show western blotting for $S$. panaciradicis). The presumed L-asparaginase bands migrated similarly to the positive control (Figure 3, lane 2); therefore, we hypothesized that the L-asparaginase enzymes from the isolated Actinobacteria had a similar molecular mass to the L-asparaginase from $E$. coli. In addition, the intensity of the band increased after each optimization step.

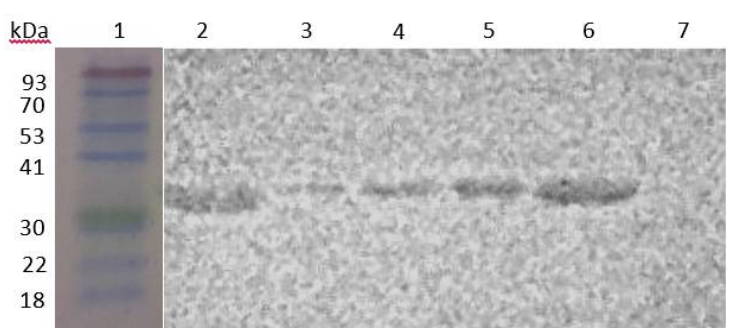

Figure 3: Western blotting analysis for L-asparaginase from Streptomyces panaciradicis. 1: Molecular weight markers (Opti-Protein XL Marker, abm®), USA); 2: Positive control, commercial L-Asparaginase $\AA$ (Medac); 3: Initial broth; 4: Best carbon source broth (1 $\%$ lactose); 5: Best nitrogen source broth $(0.5 \%$ asparagine $+0.5 \%$ malt extract); 6: Optimum conditions broth; 7: Negative control (broth with only Lglutaminase activity)

\section{Effect of carbon and nitrogen sources on L- asparaginase activity}

The nesslerization experiment showed that the best carbon source to maximize the Lasparaginase activity was lactose
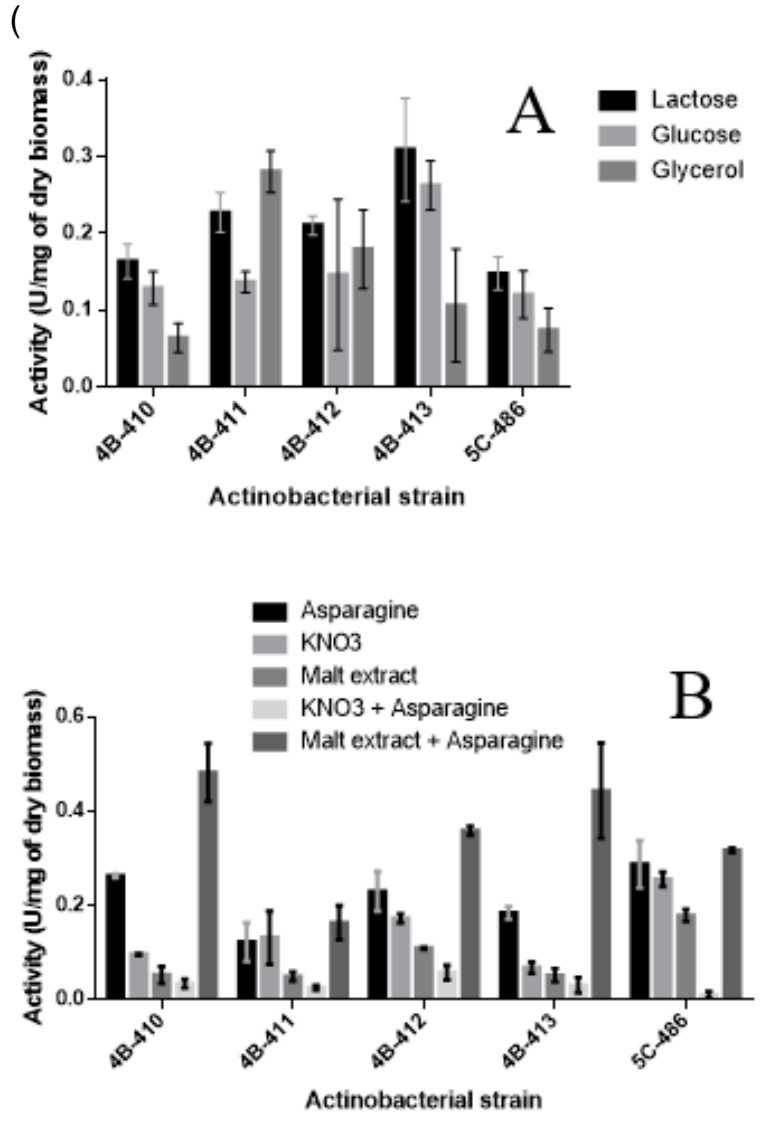

Figure $4 \mathrm{~A}$ ) and the best nitrogen source was the combination of L-asparagine with malt extract. Kitasatospora atroaurantiaca, Streptomyces seoulensis, Streptomyces griseoluteus, Streptomyces panaciradicis, and Streptomyces $\mathrm{sp}$. showed maximum L-asparaginase activities of $0.48,0.16,0.36,0.44$, and $0.32 \mathrm{U} / \mathrm{mg}$, respectively 

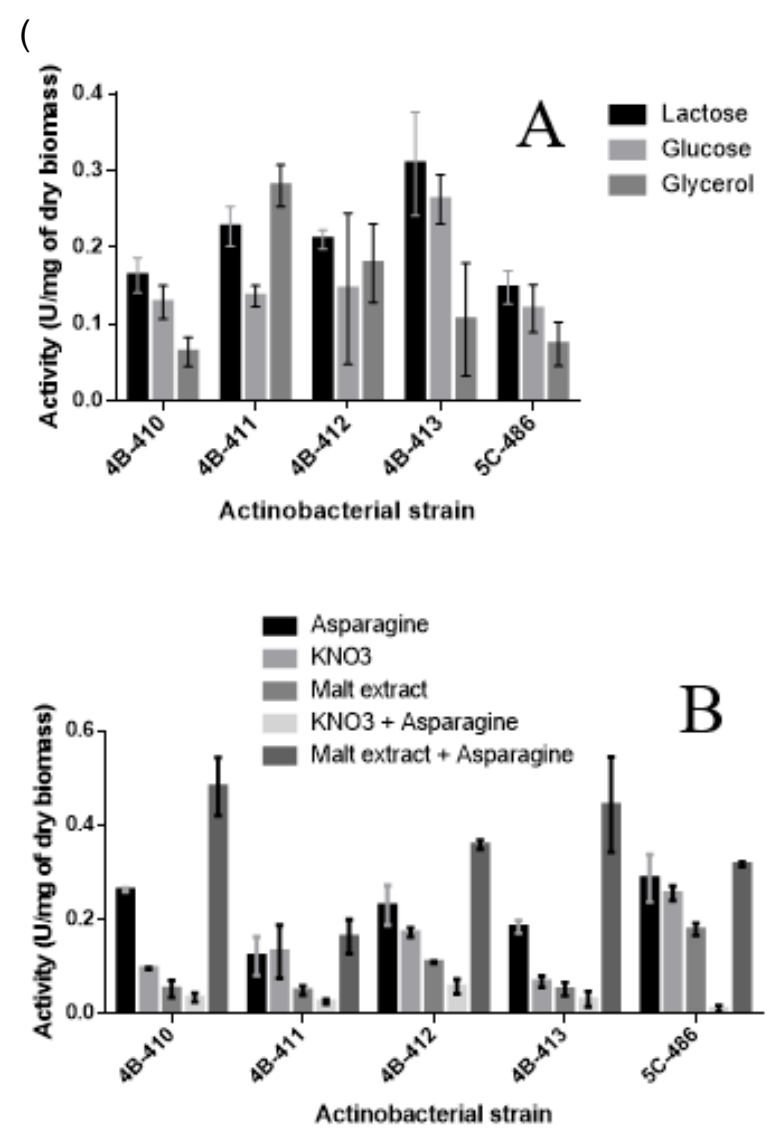

Figure 4B). Kitasatospora atroaurantiaca, Streptomyces griseoluteus, and Streptomyces panaciradicis were selected for further study.

\section{Optimized nutritional and growth factors}

Experiments were randomized using the design matrix and the experimental responses of the Lasparaginase specific activity for the different trials were assessed (

Table 2). The regression equations were obtained ANOVA analysis (Table 1). 

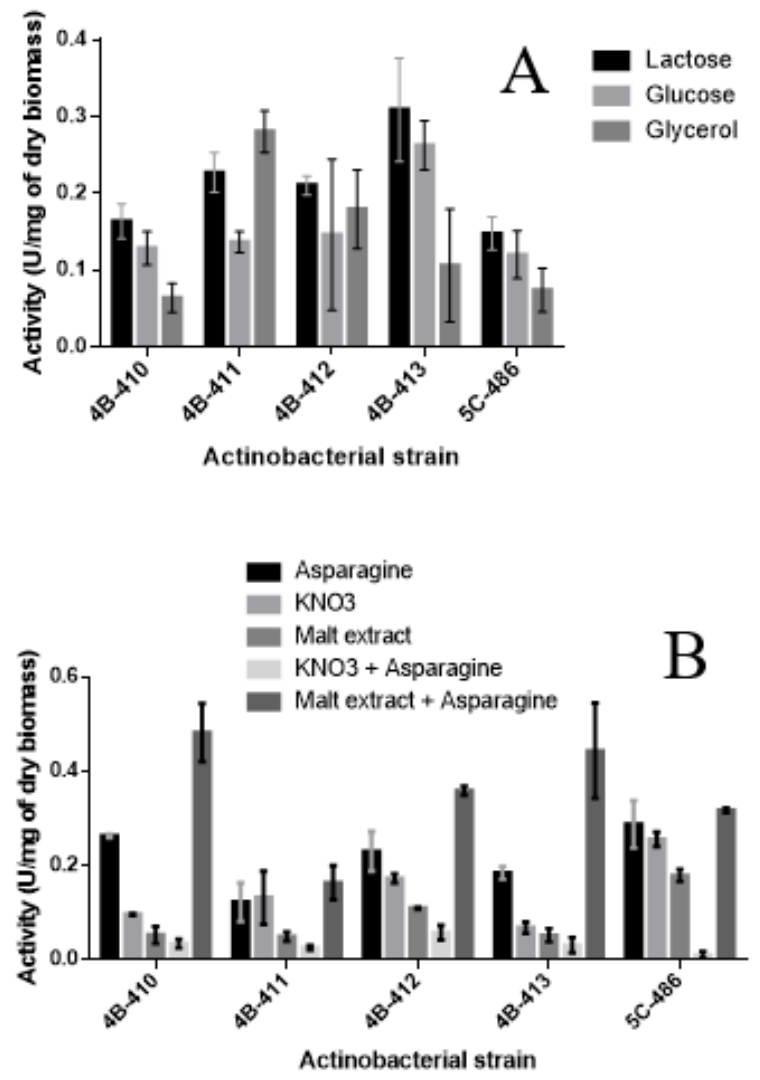

Figure 4: Nessler assay employing different carbon sources $(A)$ and different nitrogen sources $(B)$ in the medium at $1 \% \mathrm{w} / \mathrm{v}$ for each strain

Table 2: Central composite design together with the experimental L-asparaginase activity A: carbon source concentration, B: nitrogen source concentration
Table 1: Coefficients of the statistical models obtained using ANOVA

\begin{tabular}{lccc}
\hline & \multicolumn{3}{c}{ Specific activity $(\mathbf{U} / \mathbf{m g})$} \\
\cline { 2 - 4 } Variable & $\begin{array}{c}\boldsymbol{K} . \\
\text { atroaura } \\
\text { ntiaca }\end{array}$ & $\begin{array}{c}\mathbf{S} \text {. } \\
\text { griseol } \\
\text { uteus }\end{array}$ & $\begin{array}{c}\mathbf{S} \text {. } \\
\text { panacira } \\
\text { dicis }\end{array}$ \\
\hline Intercept $\left(\beta_{0}\right)$ & 556.02 & 343.59 & 1163.08 \\
Nitrogen source & 2.12 & 72.22 & 6.67 \\
concentration $\left(\beta_{1}\right)$ & & & \\
Carbon source & 23.46 & 63.53 & 125.85 \\
concentration $\left(\beta_{2}\right)$ & & & \\
Temperature $\left(\beta_{3}\right)$ & -30.69 & -21.57 & -55.38 \\
$\mathrm{pH}\left(\beta_{4}\right)$ & -31.58 & -26.36 & -123.83 \\
$\beta_{1} \times \beta_{2}$ & -3.09 & -2.22 & -5.53 \\
$\beta_{1} \times \beta_{3}$ & 0.00 & -1.86 & 0.00 \\
$\beta_{1} \times \beta_{4}$ & 0.00 & 0.00 & 0.00 \\
$\beta_{2} \times \beta_{3}$ & 0.00 & -1.81 & -1.48 \\
$\beta_{2} \times \beta_{4}$ & -2.73 & 0.00 & -10.91 \\
$\beta_{3} \times \beta_{4}$ & 1.05 & 3.84 & 2.81 \\
$\beta_{1}{ }^{2}$ & 0.00 & -2.67 & 0.00 \\
$\beta_{2}{ }^{2}$ & -0.45 & -1.68 & 0.00 \\
$\beta_{3}{ }^{2}$ & 0.41 & 0.00 & 0.66 \\
$\beta_{4}{ }^{2}$ & 0.00 & -6.62 & 3.69 \\
$\mathrm{R}^{2}$ & 0.726 & 0.826 & 0.9791 \\
\hline
\end{tabular}

All models showed statistical significance $(p<$ 0.05 ) and the lack of fit was not significant, showing correct correlation between the different studied variables and responses for strain Streptomyces panaciradicis (Table 3).

\begin{tabular}{|c|c|c|c|c|c|c|c|}
\hline \multirow[t]{2}{*}{ Run } & \multirow{2}{*}{ A \%w/v } & \multirow{2}{*}{ B \%w/v } & \multirow{2}{*}{$\begin{array}{c}\text { Temp } \\
{ }^{\circ} \mathrm{C}\end{array}$} & \multirow{2}{*}{$\mathrm{pH}$} & \multicolumn{3}{|c|}{ Activity (U/mg protein) } \\
\hline & & & & & K. atroaurantiaca & S. griseoluteus & S. panaciradicis \\
\hline 1 & 5 & 1 & 30 & 7 & 6.79 & 4.50 & 2.16 \\
\hline 2 & 1 & 1 & 30 & 7 & 7.83 & 18.34 & 4.24 \\
\hline 3 & 1 & 1 & 30 & 7 & 9.65 & 20.30 & 1.46 \\
\hline 4 & 1 & 1 & 30 & 8 & 8.64 & 3.88 & 6.85 \\
\hline 5 & 0.5 & 2.5 & 32.5 & 7.5 & 11.44 & 9.51 & 5.68 \\
\hline 6 & 0.5 & 0.5 & 27.5 & 6.5 & 3.20 & 30.72 & 7.58 \\
\hline 7 & 2.5 & 0.5 & 32.5 & 7.5 & 9.51 & 18.63 & 28.03 \\
\hline 8 & 1 & 1 & 30 & 7 & 6.66 & 3.00 & 2.34 \\
\hline 9 & 2.5 & 2.5 & 27.5 & 6.5 & 6.03 & 2.24 & 1.52 \\
\hline 10 & 2.5 & 2.5 & 32.5 & 6.5 & 10.00 & 7.54 & 5.21 \\
\hline 11 & 1 & 1 & 30 & 7 & 15.05 & 10.79 & 2.60 \\
\hline 12 & 0.1 & 1 & 30 & 7 & 2.43 & 1.62 & 0.53 \\
\hline 13 & 0.5 & 2.5 & 27.5 & 7.5 & 2.69 & 1.91 & 0.95 \\
\hline 14 & 2.5 & 0.5 & 27.5 & 7.5 & 3.99 & 11.56 & 7.82 \\
\hline 15 & 1 & 1 & 25 & 7 & 11.11 & 4.24 & 5.70 \\
\hline 16 & 1 & 5 & 30 & 7 & 4.55 & 2.28 & 1.46 \\
\hline 17 & 1 & 1 & 30 & 6 & 12.94 & 10.17 & 4.61 \\
\hline 18 & 0.5 & 0.5 & 32.5 & 6.5 & 3.00 & 1.72 & 0.76 \\
\hline 19 & 1 & 0.1 & 30 & 7 & 5.00 & 5.71 & 6.56 \\
\hline 20 & 1 & 1 & 35 & 7 & 28.18 & 22.88 & 31.20 \\
\hline 21 & 1 & 1 & 30 & 7 & 3.88 & 17.54 & 2.09 \\
\hline
\end{tabular}

Table 3: Analysis of variance for L-asparaginase activity by a central composite design (CCD) for Streptomyces panaciradicis. $(S S=$ Sum of Squares, DF = Degrees of freedom, MSS = mean sum of squares, $F=$ variance ratio, $\mathrm{p}$-value $=$ probability) 


\begin{tabular}{lccccc}
\hline Model & 1304.042 & 10 & 130.4042 & 46,8946 & $<0.0001$ \\
\hline $\begin{array}{l}\text { Nitrogen source } \\
\text { concentration }\left(\beta_{1}\right)\end{array}$ & 68.94587352 & 1 & 68.94587352 & 24.79357702 & 0.0006 \\
$\begin{array}{l}\text { Carbon source } \\
\text { concentration }\left(\beta_{2}\right)\end{array}$ & 138.954866 & 1 & 138.954866 & 49.9694615 & $<0.0001$ \\
Temperature $\left(\beta_{3}\right)$ & 0.267207332 & 1 & 0.267207332 & 0.096090241 & 0.7629 \\
$\mathrm{pH}\left(\beta_{4}\right)$ & 67.57586333 & 1 & 67.57586333 & 24.30090862 & 0.0006 \\
$\beta_{1} \times \beta_{2}$ & 105.5426859 & 1 & 105.5426859 & 37.95413095 & 0.0001 \\
$\beta_{2} \times \beta_{3}$ & 123.1318911 & 1 & 123.1318911 & 44.27937264 & $<0.0001$ \\
$\beta_{2 \times} \times \beta_{4}$ & 98.10808759 & 1 & 98.10808759 & 35.28058028 & 0.0001 \\
$\beta_{3} \times \beta_{4}$ & 98.57979866 & 1 & 98.57979866 & 35.45021197 & 0.0001 \\
$\beta_{3}{ }^{2}$ & 450.3148981 & 1 & 450.3148981 & 161.9374234 & $<0.0001$ \\
$\beta_{4}{ }^{2}$ & 22.78244813 & 1 & 22.78244813 & 8.192780129 & 0.0169 \\
Residual & 27.808 & 10 & 2.7808 & & \\
Lack of fit & 23.514 & 6 & 3.9189 & 3.6502 & 0.1153 \\
Pure error & 4.294 & 4 & 1.0736 & & \\
Total & 1331.850 & 20 & & & \\
\hline
\end{tabular}

The CCD results identified the optimal values for carbon and nitrogen source concentrations, temperature, and $\mathrm{pH}$ ( ). The maximum theoretical L-asparaginase activity for Kitasatospora atroaurantiaca was 38.7 $\mathrm{U} / \mathrm{mg}$

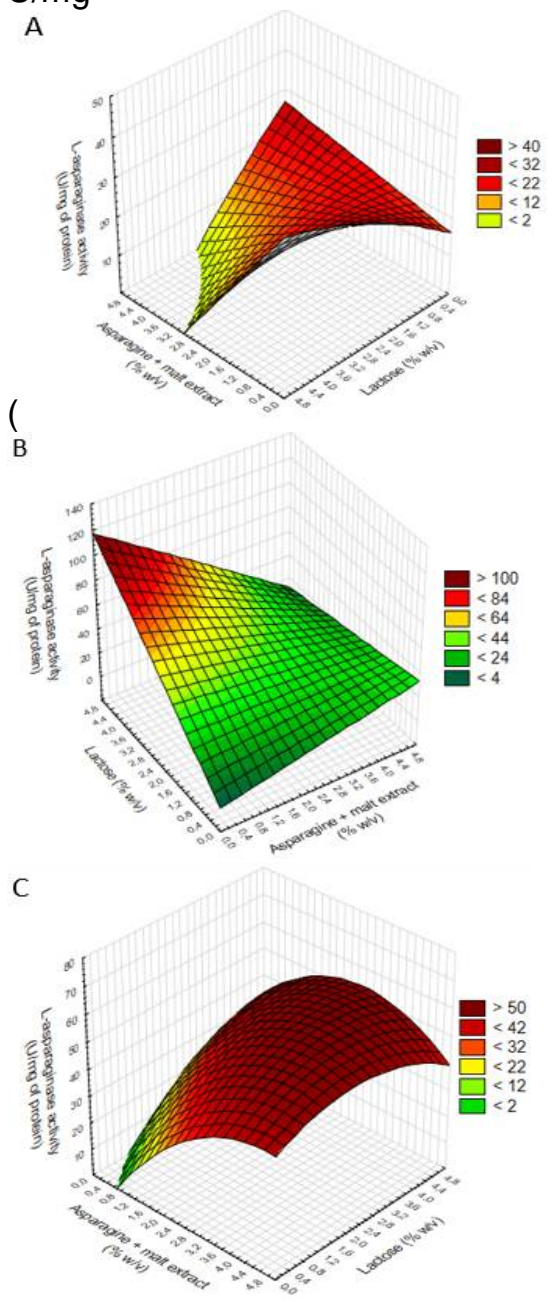

Figure $5 \mathrm{~A}$ ), for Streptomyces griseoluteus was 57.37

$\mathrm{U} / \mathrm{mg}$

A

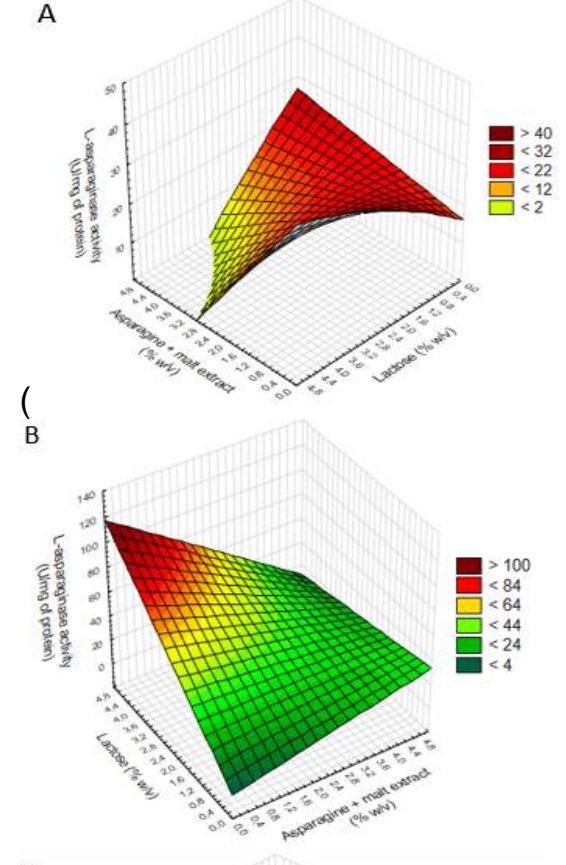

C

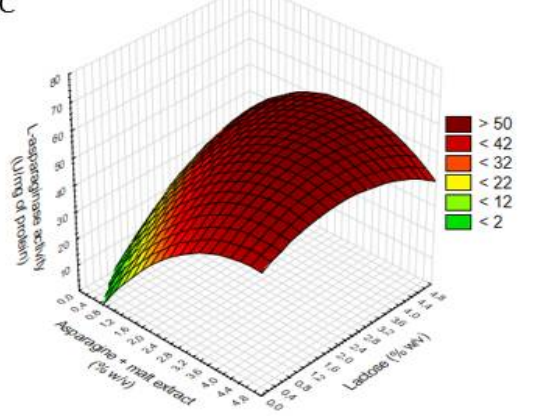

Figure 5B), and for Streptomyces panaciradicis was $\quad 114.94 \quad \mathrm{U} / \mathrm{mg}$ 
A
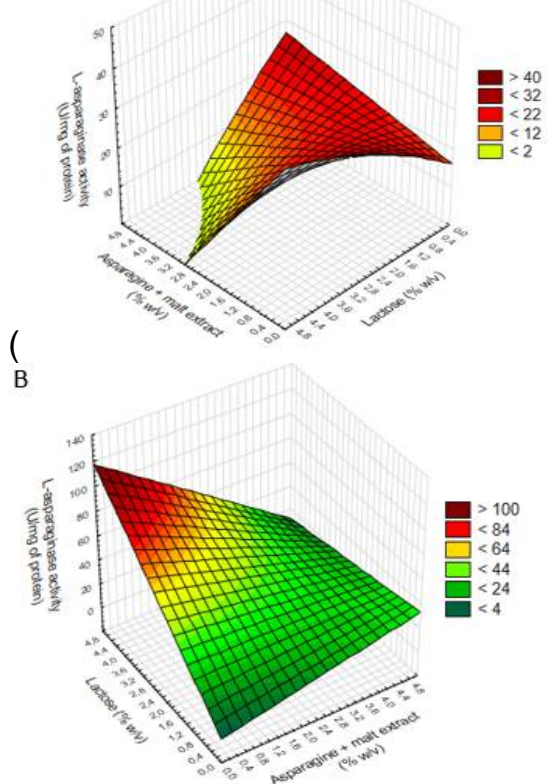

). The L-asparaginase activity of Streptomyces panaciradicis $(114.06 \mathrm{U} / \mathrm{mg}$ ) obtained from the experiment was very close to the predicted response $(114.94 \mathrm{U} / \mathrm{mg})$ from the regression
C

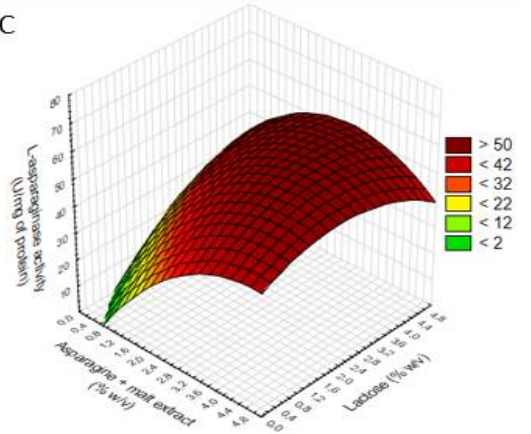

Figure 5C), indicating that Streptomyces panaciradicis had the highest L-asparaginase activity.

An experiment was carried out under the optimum conditions identified by the CCD to determine the accuracy of the models and to verify the results (

model, which proved the validity of the model. The verification revealed that the model was very accurate, with an error rate of only $0.77 \%$ under the tested conditions ( ).

Table 4: Verification of the accuracy of the models obtained with CCD. A: Carbon source concentration, B: Nitrogen source concentration

\begin{tabular}{|c|c|c|c|c|c|c|c|}
\hline \multirow{2}{*}{ Strain } & \multirow{2}{*}{$\begin{array}{c}A \\
(\% \mathrm{w} / v)\end{array}$} & \multirow{2}{*}{$\begin{array}{c}\text { B } \\
(\% \text { w/v) }\end{array}$} & \multirow{2}{*}{$\begin{array}{c}\text { Temp } \\
{ }^{\circ} \mathrm{C}\end{array}$} & \multirow{2}{*}{$\mathrm{pH}$} & \multicolumn{2}{|c|}{ Activity (U/mg protein) } & \multirow{2}{*}{ Error (\%) } \\
\hline & & & & & Experimental & Predicted & \\
\hline K. atroaurantiaca & 0.1 & 5 & 25 & 6 & 29.4 & 23.28 & 26 \\
\hline S. griseoluteus & 5 & 0.0 & 25 & 6 & 34.08 & 34.66 & 1.7 \\
\hline S. panaciradicis & 5 & 0.1 & 25 & 6 & 114.06 & 114.94 & 0.8 \\
\hline
\end{tabular}

A

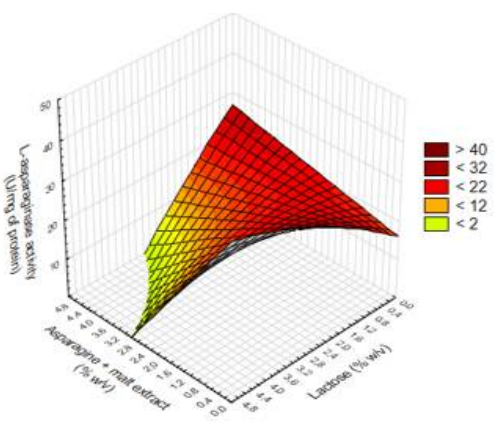

B
C
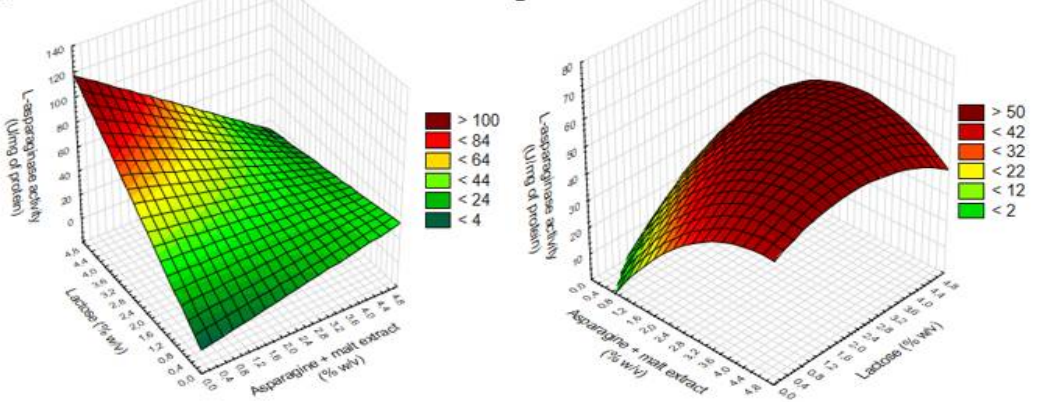

Figure 5: Surface plots for interactions between nitrogen and carbon source concentrations with L-asparaginase activity for A: Kitasatospora atroaurantiaca, B: Streptomyces griseoluteus, and C: Streptomyces panaciradicis

Table 5: Cytotoxic activity of broths with L-asparaginase activity on the MDA cell line and the $\mathrm{IC}_{50}(\mathrm{ppm})$ value for each strain

\begin{tabular}{lccccccc}
\hline & \multicolumn{2}{c}{ K. atroaurantiaca } & \multicolumn{2}{c}{ S. griseoluteus } & \multicolumn{2}{c}{ S. panaciradicis } & Doxorubicin \\
\cline { 2 - 8 } $\begin{array}{l}\text { Concentration } \\
\text { (ppm) }\end{array}$ & $\begin{array}{c}\text { Cytotoxicity } \\
(\%)\end{array}$ & $\begin{array}{c}\text { Enzymatic } \\
\text { activity } \\
(\mathbf{m U} / \mathbf{m L})\end{array}$ & $\begin{array}{c}\text { Cytotoxicity } \\
(\%)\end{array}$ & $\begin{array}{c}\text { Enzymatic } \\
\text { activity }(\mathbf{m U} / \mathbf{m L})\end{array}$ & $\begin{array}{c}\text { Cytotoxicity } \\
(\%)\end{array}$ & $\begin{array}{c}\text { Enzymatic } \\
\text { activity } \\
(\mathbf{m U} / \mathbf{m L})\end{array}$ & $\begin{array}{c}\text { Cytotoxicity } \\
(\%)\end{array}$ \\
\hline 10 & $41.2 \pm 0.76$ & 0.307 & $22.2 \pm 5.51$ & 0.207 & $59.3 \pm 3.40$ & 0.236 & $19.3 \pm 0.35$ \\
20 & $45.9 \pm 2.50$ & 0.614 & $34.6 \pm 4.47$ & 0.414 & $64.7 \pm 3.38$ & 0.471 & $62.9 \pm 0.05$ \\
50 & $55.7 \pm 4.38$ & 1.535 & $36.6 \pm 5.06$ & 1.035 & $60.5 \pm 5.90$ & 1.178 & $78.0 \pm 0.02$ \\
100 & $47.8 \pm 5.67$ & 3.07 & $34.7 \pm 6.52$ & 2.07 & $64.0 \pm 0.70$ & 2.356 & $76.3 \pm 0.09$ \\
200 & $56.2 \pm 1.18$ & 6.139 & $53.1 \pm 2.20$ & 4.139 & $66.7 \pm 0.56$ & 4.713 & $80.6 \pm 0.02$ \\
\hline
\end{tabular}




\begin{tabular}{llllllll}
\hline $\mathrm{IC}_{50}(\mathrm{ppm})$ & $25.61 \pm 2.15$ & 0.786 & $165.29 \pm 1.06$ & 3.421 & $8.18 \pm 1.61$ & 0.190 & $1.95 \pm 0.25$ \\
\hline
\end{tabular}

The results are expressed as mean $\pm \operatorname{SD}(n=6)$

\section{Cytotoxic activity}

MDA cells exposed to diverse concentrations of protein broths with L-asparaginase activity showed a dose-dependent decrease in viabilitycompared with untreated cells after $48 \mathrm{~h}$ of treatment. The protein broths from the strains presented a half maximal inhibitory concentration $\left(\mathrm{IC}_{50}\right)$ between 1 and $200 \mathrm{ppm}$ on the MDA cell line (Table 5). The $\mathrm{IC}_{50}$ value of doxorubicin was less than $10 \mathrm{ppm}$ against the L929 cell line. The $I_{50}$ values for each enzymatic broth were greater than 200 ppm against L929 cells.

\section{DISCUSSION}

When used in chemotherapy, L-asparaginase caused problems related to its side effects associated with its L-glutaminase activity.

the present study, we found that L-asparagine and malt extract stimulated L-asparaginase activity more than using one nitrogen source alone. However, for all the strains evaluated, Lasparagine was not essential to obtain Lasparaginase activity, as seen when malt extract or potassium nitrate alone were used as nitrogen sources.

For Kitasatospora atroaurantiaca and $S$. panaciradicis, temperature showed a quadratic relationship with the L-asparaginase activity, whereby there was a maximum value beyond which an increase in the factor did not correspond to an increase in activity. The concentrations of carbon and nitrogen sources showed an inverse correlation with the L-asparaginase activity in Streptomyces panaciradicis.

The L-asparaginase activities obtained from Streptomyces panaciradicis $(114.06 \mathrm{U} / \mathrm{mg})$, Streptomyces griseoluteus (34.08 U/mg), and Kitasatospora atroaurantiaca $(29.4 \mathrm{U} / \mathrm{mg})$ were much greater than those attained from other microorganisms, such as Aspergillus terreus (10.97 U/mg) [10], Streptomyces thermoluteus (4.6 U/mg), and Streptomyces avermitilis (5.6 $\mathrm{U} / \mathrm{mg}$ ) [26]. Kumari et al [17] reported the production of L-asparaginase from Streptomyces griseoluteus isolated form marine sediments, with a enzymatic activity of $16.88 \mathrm{U} / \mathrm{mg}$ before purification. Therefore, the three strains identified in the present study produced L-asparaginase with high activity and low levels of L-glutaminase activity.
Therefore, in the present study, we identified five Actinobacterial strains with high L-asparaginase and no L-glutaminase activity.

Different carbon sources have different effects on L-asparaginase production from Streptomyces. $S$. longsporusflavus and $S$. albidoflavus produced the maximum amount of $\mathrm{L}$ asparaginase when grown on soluble starch $[13,23]$ whereas $S$. phaeochromogenes and $S$. tendae produced the maximum activity on glycerol and sucrose, respectively [24]. However, few studies used lactose for Actinobacterial Lasparaginase production. Furthermore, the nitrogen sources used during fermentation has an impact on L-asparaginase production $[1,2,19]$. El-naggar et al [25] suggested that Lasparaginase activity increases with the concentration of L-asparagine in the medium. In

The Streptomyces panaciradicis, Streptomyces griseoluteus, and Kitasatospora atroaurantiaca Lasparaginases displayed similar cytotoxic activities against MDA cells $(0.190,3.421$, and $0.786 \mathrm{mU} / \mathrm{mL}$, respectively) compared with other bacterial L-asparaginases. L-asparaginase purified from Enterobacter cloacae showed an $\mathrm{IC}_{50}$ value of approximately $11.8 \mathrm{U} / \mathrm{mL}$ [27] and Pokrovskaya et al [28] reported that the recombinant L-asparaginase produced by Yersinia pseudotuberculosis showed an $\mathrm{IC}_{50}$ value of $10 \mathrm{U} / \mathrm{mL}$.

\section{CONCLUSION}

Streptomyces griseoluteus, Kitasatospora atroaurantiaca, and Streptomyces Panaciradicis (the last two reported for the first time as Lasparaginase producers) are potential sources of L-asparaginase with low L-glutaminase activity. Optimizing the nutritional and growth factors of Kitasatospora atroaurantiaca, Streptomyces griseoluteus, and Streptomyces panaciradicis increases L-asparaginase activity between 9 and 90 times. L-asparaginases from these strains possess good cytotoxicity against MDA-MB-231 cells in vitro and low performance on the untransformed cell line L929, suggesting they are good candidates for the treatment of acute lymphoblastic leukemia.

\section{DECLARATIONS}

\section{Acknowledgement}

This research was substantially supported by La Sabana University through the group ProNIUS. 


\section{Conflict of Interest}

No conflict of interest associated with this work.

\section{Contribution of Authors}

The authors declare that this work was done by the authors named in this article and all liabilities pertaining to claims relating to the content of this article will be borne by them.

\section{REFERENCES}

1. Shrivastava $A$, Khan $A A$, Khurshid $M$, Kalam MA, Jain SK, Singhal PK. Recent developments in l-asparaginase discovery and its potential as anticancer agent. Crit Rev Oncol Hematol 2015; 100: 1-12.

2. Silpa $S$, Bhattacharya $S$, Venkatanagaraju E. Overview on L-asparaginase. World J Pharm Pharm Sci 2017; 6(5): 561-601.

3. Vidya J, Sajitha S, Ushasree MV, Sindhu R, Binod $P$, Madhavan A, Pandey A. Genetic and metabolic engineering approaches for the production and delivery of L-asparaginases: An overview. Bioresour Technol 2017; 245(Part B): 1775-1781.

4. Hunger SP, Lu X, Devidas M, Camitta BM, Gaynon PS, Winick NJ, Reaman GH, Carroll WL. Improved survival for children and adolescents with acute lymphoblastic leukemia between 1990 and 2005: a report from the children's oncology group. J Clin Oncol 2012; 30(14): 1663-1669.

5. Ali U, Naveed M, Ullah A, Ali K, Shah SA, Fahad $S$, Mumtaz AS. L-asparaginase as a critical component to combat Acute Lymphoblastic Leukaemia (ALL): A novel approach to target ALL. Eur J Pharmacol 2016; 771: 199-210.

6. El-sayed ST, Fyiad A, Gamal-eldeen AM. Immobilization, Properties and Anti-tumor Activity of L-asparaginase of Vicia faba and Phaseoulus vulgaris Seeds. Aust $J$ Basic Appl Sci 2012; 6(3): 785-794.

7. Subramani R, Aalbersberg W. Marine actinomycetes: An ongoing source of novel bioactive metabolites. Microbiol Res 2012; 167(10): 571-580.

8. Derst C, Henseling J, Röhm KH. Engineering the substrate specificity of Escherichia coli asparaginase. II. Selective reduction of glutaminase activity by amino acid replacements at position 248. Protein Sci 2000; 9(10): 2009-2017.

9. Meena B, Anburajan L, Sathish T, Vijaya RR, Dharani G, Vinithkumar NV, Kirubagaran R. L-Asparaginase from Streptomyces griseus NIOT-VKMA29: optimization of process variables using factorial designs and molecular characterization of L-asparaginase gene. Sci Rep 2015, 5(12404): 1-12.

10. Farag AM, Hassan SW, Beltagy EA, El-Shenawy MA. Optimization of production of anti-tumor l-asparaginase by free and immobilized marine Aspergillus terreus. Egypt J Aquat Res 2015; 41(4): 295-302.
11. Thaer TA, Ellaiah P. L-Asparaginase production by a streptomycete and optimization of production parameters. J Pharm Biomed Sci 2013; 29: 859-868.

12. El-Naggar NE, Moawad H, Abdelwahed NAM. Optimization of fermentation conditions for enhancing extracellular production of L-asparaginase, an antileukemic agent, by newly isolated Streptomyces brollosae NEAE-115 using solid state fermentation. Ann Microbiol 2016; 67(1): 1-15.

13. Deshpande N, Choubey $P$, Agashe M. Studies on optimization of growth parameters for L-asparaginase production by Streptomyces ginsengisoli. Sci World J 2014; 895167: 1-7.

14. El-naggar NE, Moawad H, El-shweihy NM, El-ewasy SM. Optimization of Culture Conditions for Production of the Anti-Leukemic Glutaminase Free L-Asparaginase by Newly Isolated Streptomyces olivaceus NEAE-119 Using Response Surface Methodology. Biomed Res Int 2015; 627031: 1-17.

15. Pradhan B, Dash SK, Sahoo S. Screening and characterization of extracellular $L$-asparaginase producing Bacillus subtilis strain hswx88, isolated from Taptapani hotspring of Odisha, India. Asian Pac J Trop Biomed 2013; 3(12): 936-941.

16. Basha NS, Rekha R, Komala M, Ruby S. Production of Extracellular Anti-leukaemic Enzyme L-asparaginase from Marine Actinomycetes by Solid-state and Submerged Fermentation: Purification and Characterisation. Trop J Pharm Res 2009; 8: 353-360.

17. Kumari PVK, Sankar GG, Prabhakar T, Lakshmi SS. Purification and Characterization of L-Asparaginase from Streptomyces griseoluteus WS3/1. Int J Pharm Pharm Sci 2013; 23(2): 198-202.

18. Pastrana-Camacho N, Suárez Z, Acosta-González A, Arango C, Haltli B, Correa H, Kerr R, Duque C, Díaz LE. Bioprospecting for culturable actinobacteria with antimicrobial properties isolated from rivers in Colombian Orinoquia. Trop J Pharm Res 2016; 15(6): 1259-1265.

19. Mostafa EE, El-deen AMN, Awad HM, Mamdouh A. Partial characterization of $L$-asparaginase-producing by Streptomyces sp. SAH1 _ CWMSG isolated from Rizosphere soil in Egypt. J Chem Pharm Res 2016; 8(4): 1290-1307.

20. Arrivukkarasan S, Muthusivaramapandian M, Aravindan $R$, Viruthagiri T. Effect of Medium Composition and Kinetic Studies on Extracellular and Intracellular Production of $L$-asparaginase from Pectobacterium carotovorum. Food Sci Technol Int 2010; 16(2): 115125.

21. Abakumova OY, Podobed OV, Karalkin P, Kondakova LI, Sokolov NN. Antitumor activity of L-asparaginase from Erwinia carotovora against different human and animal leukemic and solid tumor cell lines. Biochem Suppl Ser B Biomed Chem 2012; 6(4): 307-316.

22. Meena B, Anburajan L, Valsalan N, Shridhar D, Vijaya R, Dharani G, Kirubagaran R. Molecular expression of $L$ asparaginase gene from Nocardiopsis alba NIOT-

Trop J Pharm Res, November 2018; 17(11): 2208 
VKMA08 in Escherichia coli: A prospective recombinant enzyme for leukaemia chemotherapy. Gene 2016; 590(2): 220-226.

23. Meena B, Anburajan L, Dheenan $P$, Begum $M$, Vinithkumar $N$, Dharani G, Kirubagaran $R$ Novel glutaminase free $L$-asparaginase from Nocardiopsis alba NIOT-VKMA08: production, optimization, functional and molecular characterization. Bioprocess Biosyst Eng 2015; 38(2): 373-388.

24. Kavitha A, Vijayalakshmi M. Optimization and Purification of L-Asparaginase Produced by Streptomyces tendae TK-VL_ 333. J Biosci 2010; 65: 528-531.

25. El-naggar NE, Deraz SF, Soliman HM, El-deeb NM. Purification, characterization, cytotoxicity and anticancer activities of L-asparaginase, anti-colon cancer protein, from the newly isolated alkaliphilic Streptomyces fradiae NEAE-82. Sci Rep 2016; 6:32926: 1-16.
26. Hatanaka T, Usuki H, Arima J, Uesugi $Y$, Yamamoto $Y$, Kumagai $Y$, Yamasato A, Mukaihara T. Extracellular production and characterization of two Streptomyces Lasparaginases. Appl Biochem Biotechnol 2011; 163(7): 836-844.

27. Husain I, Sharma A, Kumar S, Malik F. Purification and characterization of glutaminase free asparaginase from Enterobacter cloacae: In-vitro evaluation of cytotoxic potential against human myeloid leukemia HL-60 cells. PLoS One 2016; 11(2): 1-27.

28. Pokrovskaya MV, Aleksandrova SS, Pokrovsky VS, Omeljanjuk NM, Borisova AA, Anisimova NY, Sokolov $N N$. Cloning, expression and characterization of the recombinant Yersinia pseudotuberculosis Lasparaginase. Protein Expr Purif 2012; 82(1): 150-154. 